\title{
Importance of Transport Corridors in Regional Development: The Case of TRACECA ${ }^{1}$
}

Hilal YILDIRIR KESER, Logistics Programme, Vocational School of Social Sciences, Uludag University, Turkey; e-mail: hilalyildirir@uludag.edu.tr

\section{Bölgesel Kalkınmada Ulaştırma Koridorlarının Önemi: TRACECA Örneği²}

\begin{abstract}
After the Second World War regional development has been an important subject of economic analysis. Transport activities and developing transport corridors have been observed among the most important factors in ensuring regional development. One of the most comprehensive transport corridors is the TRACECA (Europa-Caucasus-Asia Transport Corridor) corridor which is referred to as the New Silk Road. The TRACECA corridor has been thought to play an important role in Turkey's all kinds of passenger and freight transport, use of the potential in terms of tourism and trade, and regional development. With this point of view in mind, in the study, it has been aimed to reveal the effects of TRACECA corridor on the economic potential and regional development. Within this context, firstly the regional development has been handled. Then, referring to the transport corridors, TRACECA corridor has been explained, and the effects of TRACECA towards regional development have been discussed.
\end{abstract}

Keywords

JEL Classification Codes $\quad: \quad \mathrm{R} 1, \mathrm{~F} 1, \mathrm{~F} 63$.

\section{Öz}

II. Dünya savaşı sonrasında bölgesel kalkınma önemli bir iktisadi analiz konusu olmuştur. Ulaştırma faaliyetleri ve gelişen ulaştırma koridorları bölgesel kalkınmanın sağlanmasında önemli faktörler arasında görülmektedir. Ulaştırma koridorlarının en kapsamlı olanlarından biri, Yeni İpek Yolu olarak ifade edilen TRACECA (Avrupa- Kafkasya-Asya Ulaştırma Koridoru) Koridoru'dur. TRACECA koridorunun, Türkiye'nin her türlü yük ve yolcu taşımacılığı, ticaret ve turizm konusunda potansiyelini kullanmasında ve bölgesel kalkınmasında önemli rol oynadığı düşünülmektedir. Bu düşünceden hareketle çalışmada, TRACECA koridorunun ekonomik potansiyele ve bölgesel kalkınmaya etkilerinin ortaya konulması amaçlanmaktadır. Bu kapsamda ilk olarak, bölgesel kalkınma ele alınmaktadır. Sonrasında, ulaştırma koridorlarına değinilerek TRACECA koridoru açıklanmakta ve TRACECA'nın bölgesel kalkınmaya yönelik etkileri tartışılmaktadır.

Anahtar Sözcükler $\quad$ : Bölgesel Kalkınma, Ulaştırma Koridoru, TRACECA, Yeni İpek yolu.

1 This paper is an extended and revision of the congress paper: "Bölgesel Kalkınmada Ulaştırma Koridorlarının Önemi: TRACECA Örneğ $i$ ” presented at the International Turgut Ozal Congress on Business, Economics and Political Science (01-03 November 2013).

2 Bu çalışma, International Turgut Ozal Congress on Business, Economics and Political Science (01-03 November 2013) isimli kongrede sunulan "Bölgesel Kalkınmada Ulaştırma Koridorlarının Önemi: TRACECA Örneği”" başlıklı tebliğin genişletilmiş ve düzenlenmiş halidir. 


\section{Introduction}

Economic development which is the main target of the countries, refers to the modification of economic and socio-cultural structure in the developing societies besides increasing the production and the per capita income. However, changes in the amount and effectiveness of production factors, structural changes such as increasing the share of national income and exports of industrial sector constitute the essential elements of development (Kebabçı, 2011: 15).

Countries, using their existing resources and facilities in the most efficient way, are trying to reach their economic development objectives. However, in this process, the concentration of economic and socio-cultural activities in certain centers in both developed countries and the developing countries causes the appearance of inter-regional development differences and consequently imbalances between these regions. This situation has been discomposes the economic effectiveness, population distribution, and integrity of cities, environment and natural texture and increases the economic and social costs of development.

Inter-regional development disparities requires the improvement of the policies towards bringing the less developed regions closer to the developed regions in terms of welfare. This case leads "region" and "development" concepts to be handled as a whole and the concept of "regional development" has been gaining importance day by day (Armstrong, 2005: 276).

One of the most important factors that lead to inter-regional disparities, is expressed as the uneven distribution of transport infrastructure among the regions. Transport infrastructure is composed of transportation systems such as road, rail, sea, air, inland waterways and pipelines. These transportation systems provides transportation of the raw materials and intermediate goods to the place of production and final products to the target markets. According to the traditional point of view in the regional development literature, the development of transport infrastructure is considered as a prerequisite for the initiation of regional development (Saatçioğlu-Khan, 2013: 1).

Transport activities all over the world have been carried out on the route called the transportation corridor throughout history. The transport corridors initially used as transport-oriented have overtime become a policy tool enabling regional development by means of strengthening the transport infrastructure particularly of the underdeveloped regions on the corridors, attracting foreign investment and increasing employment by establishing logistics centers in these regions. Also known as the Old Silk Road, The multimode TRACECA (Euro-Caucasus-Asia Transport Corridor) which has been enhanced by the European Union in order to integrate the continents of Asia and Europe by connecting them over the Black Sea and the Caucasus has been considered to make significant 
contribution to regional development of the member countries including Turkey by successfully enabling the construction of the physical and institutional infrastructure in the regions on the corridor.

In this study, the possible effects of the TRACECA on the regional development have been discussed. In this context, primarily the regional development has been handled theoretically. Secondly, the importance of transport activities and transport corridors on regional development has been referred to. The study concludes by evaluating the effects of TRACECA which is a comprehensive transport corridor on the member countries and Turkey.

\section{Regional Development}

Regional development can generally be defined as the economic, social and demographic indicators reaching to a more advanced stage and increasing the life quality of the people living in this region (Özgür, 2010: 18). In other words, the regional development can be expressed as increasing the level of income and employment and raising the standard of living of the region by mobilizing the region's own resources and encouraging entrepreneurship (Durgun, 2006: 42).

When "the Regional Development" is considered at the definitional level, the meaning imposed on this concept can greatly vary depending on the area definition. Regional development level difference in the world can occur between continents, between countries, between the regions-areas in the same city and the districts of a city. Definition of region and determination of area must be made with a polarized region if economic priorities are taken into initial plan, with a basin or geographical region if environmental and economic criteria are taken into account, and with a political region if cultural-historical criteria taken as the base. If the definition of region is kept broad the aim of the development effort is the development regions, and if it is kept narrow it is the enlargement spots. Therefore, in the development effort of any region the way that the definition of region is made has great importance (Arslan, 2005: 279).

Theoretical foundations of regional development that entered the economics literature after the World War 2 is based on Von Thünen's study of the area economics. Von Thünen has seen that transport expenditures become a major obstacle in production and has tried to identify which product's growth would be more economical while getting away from the target market. Von Thünen's works has provided the emergence and development of the Classic Trade Theory with Ricardo, Heckscher-Ohlin and Samuelson, the Site Selection Theory with Weber, Lösch and Isard, and the Polarization Theory with Perroux, North, Myrdal, Hirschman and Kaldor (Beceren, 2004: 281). While sorting the stages of regional development process, North (1955) has expressed that a region where production is made at 
self-sufficient level can initiate its development process with development of its transport infrastructure. Improvements in transport infrastructure will open the way of regional development since they will bring along the trade and specialization. Myrdal (1957), stated that the construction and maintenance of a good transport network as one of the requirements of regional economic development. Since the improvement of trade relations will be difficult in an area that does not have a good transportation network, it will remain behind the others in terms of regional development (Saatçioğlu \& Karaca, 2013: 2).

Theoretical approaches to regional development can be grouped under four main headings. These can be specified as; Regional Growth Models, Polarized Development Theories, New Theories and Alternative Approaches to Regional Development (Ildirar, 2004: 46). These approaches are seen in Table 1.

\section{Table: 1}

\section{Theoretical Approaches to Regional Development}

\begin{tabular}{|c|c|c|c|}
\hline Regional growth Models & $\begin{array}{l}\text { Polarized } \\
\text { Development Models }\end{array}$ & New Theories & $\begin{array}{l}\text { Alternative Approaches } \\
\text { to Regional Development }\end{array}$ \\
\hline $\begin{array}{l}\text { *Keynesian Regional Growth } \\
\text { Models }\end{array}$ & \multirow{4}{*}{$\begin{array}{l}\text { *Sectorial Polarized } \\
\text { development models } \\
\text { *Regional Polarized } \\
\text { development models }\end{array}$} & \multirow{4}{*}{$\begin{array}{l}\text { *New Growth } \\
\text { Theory } \\
\text { *New Economic } \\
\text { Geography Theory }\end{array}$} & \\
\hline $\begin{array}{l}\text { *Neo-Classic Regional Growth } \\
\text { Models }\end{array}$ & & & * Long Waves Theory \\
\hline $\begin{array}{l}* \text { Export-demand models and models } \\
\text { based on the cumulative causation }\end{array}$ & & & $\begin{array}{l}* \text { Flexible Specialization } \\
\text { and Production Theory }\end{array}$ \\
\hline $\begin{array}{l}\text { Growth Process } \\
\text { *Regional Econometric Growth } \\
\text { Models }\end{array}$ & & & $\begin{array}{l}* \text { Innovative Environment } \\
\text { and Network Approaches }\end{array}$ \\
\hline
\end{tabular}

Source: Ildirar, 2004: 46.

Theories for regional development can be divided into two as containing and noncontaining the space (geography). Regional development models not containing the space mostly consists of the adaptation of neo-classical growth theory and its derivatives to regional economy, and relates the regional income differences to the differences of capital accumulation, labor power and technological development. In these theories, since the space is not given a place, transport infrastructure does not take place. However, in most of the regional development models containing space transportation costs is an important factor, because of the effects on transportation costs, transport infrastructure becomes effective on regional development (Saatçioğlu \& Karaca, 2013: 2).

Today, in many developed and developing countries, economic activities showing differences according to location and consequently so as the distribution of wealth, causes the countries to focus more on the issues of regional development and to improve policies 
and strategies in this direction. Policies implemented for regional development, provides a variety of benefits to the national economy. Some of these benefits can be specified as the increasing the rate of development by making use of the resources located in different regions of a country in the economic activities, the establishment of population-resource balance in the country, and elimination of welfare disparities between the regions (Kebapç1, 2011: 15).

\section{Transport Activities and Transport Corridors in Regional Development}

Today, the movement of goods has gained importance due to the increasing in the international trade depending on the globalization activities. While domestic products are exported to many countries, many other products which are competitors of the domestic products with the demand of consumers in the country are imported. However, carrying agrifood requirements from the rural areas in a region, meeting the raw material requirements of the industry located in the city, workers easily performing journey between home and the workplace can only be realized with transport activities. Therefore, transport activities of which demand is shaped by the intensity of goods and passenger movements is an important economic activity. However, when viewed from the other side, the cost of transport activities also affect the touristic demands of passengers and trade of goods.

Transportation activities, has a special importance in achieving economic development. The low costs related to transportation activities, creates an effect of increasing productivity. For example, when the freight rate of an imported goods falls, the profit rate gained from trade increases and more goods and services are produced. Increase in production contributes to economic development by increasing employment and prosperity (Litman, 2010: 7).

Fig. 1

\section{Impacts of Transportation Operations on Economic Development}

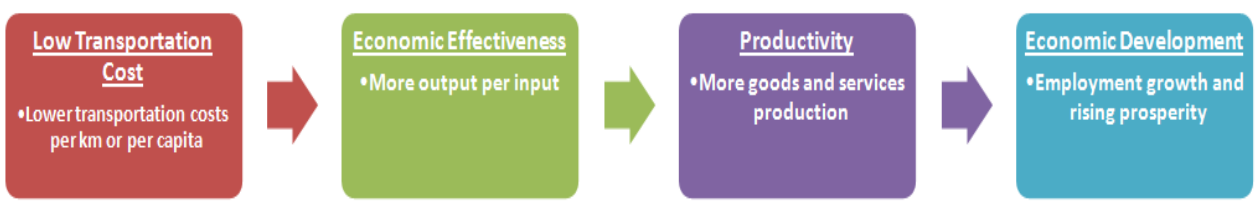

Source: Litman, 2010: 7.

Economic impacts caused by transport activities can be grouped under three main headings, including direct, indirect and related effects. Direct effects can be specified as 
employment creation, easy access to larger markets, increasing its market share, time and cost savings. Indirect effects are the effects created by the multiplier effects of transport activities. For example the reflection of new products and decreasing transport costs on production costs, the increasing diversity of goods can be expressed as indirect effects. This situation occurring in a particular sector increases the demand and it affects employment in that sector. And the dependent effects are the effects that transport activities create in other goods and services sectors. For example, in steel industry, to import iron with convenient transportation costs will cause the production cost thus the export price become low can increase the volume of exports. Realization export also requires efficiency in transportation activities (Rodrigue, 2013: 252).

The economic importance that transport activities have requires making infrastructure planning every day towards developing transport facilities. Transport activities can only create mentioned economic impacts as long as powerful infrastructure exists. When looked overall, it is seen that the regions that have powerful infrastructure and where transportation facilities can easily be improved have more advantages compared with other regions (Öztürk \& Uzun, 2010: 95). For example, the level of development of the port cities such as İstanbul and İzmir where the maritime, rail, air transport can be used in a more integrated manner is much higher than other cities. The uneven distribution of transport infrastructure among the regions causes regional development differences.

Today, realization of transport activities between countries and providing the infrastructure to ensure the realization uninterruptedly is made possible by the international transport corridors. It is thought that transportation corridors create developing effects on the geography along the corridor by enabling the realization of the international transport faster, more effectively and less costly.

\subsection{Transport Corridors and Its Content}

International transport corridors, in other words transport networks, take place among the topics that The United Nations focus importance on in order to improve international trade and tourism.

There are several definitions in the literature related to the transport corridors. According to common definition, one or more than one route that links the centers where economic activities are carried out is called the transport corridor. International transport corridors connect one or more than one neighboring countries together, landlocked countries are provided coast connection by means of one or more transit countries. Transport corridors are planned primarily for realization of regional development by providing transportation and logistics services to the cities and countries on the route (Arnold, 2005: 1). 
Transport corridors, according to another definition, is defined as the transport infrastructure works that enable all modes of transport to be used in an integrated manner (Florkowski \& Nilsson, 2007: 4). Transport of the goods which are the subject of trade in a most reasonable cost and the fastest way is the primary target in international trade.

The development of transport corridors can be summarized in four stages (Banomyong, 2008: 17). These are in the form of:

\section{i Transport Corridors \\ ii Multimodal Transport Corridors \\ iii Logistics Corridors \\ iv Economic Corridors.}

International networks are the networks that have emerged as transportationoriented corridors. The transport corridors being the first stage, establish a physical connection between certain regions only. Multi-modal transport corridors being the second stage, unlike the first are the corridors allowing multi-modal transport in certain regions. Logistics corridors being the third stage, are the corridors that provide connection between the logistics centers (hub) in certain regions. Logistics centers are the centers where all kinds of transport modes are enabled and logistics services such as storage, handling and customs clearance are provided. Since the logistics corridors are established between these centers, they have more effectiveness. Logistics corridors, different from the others, require institutional structures simplifying the processes. This institutional structure helps to eliminate bottlenecks in customs that apply to all corridors (Mulenga, 2013: 10).

The economic corridors are the most advanced form of international corridors. However, such corridors do not focus on economic development of large cities, the corridors passing through the smaller cities and rural areas to which investments are directed and which are developing and development of these regions gain importance. In this case, in the countries where the corridor passing, regulations and incentives are needed to attract private sector investments. The success of the economic corridors depends on investments towards physical and institutional infrastructure (Mulenga, 2013: 10).

Currently, there are many international corridors. Most of them has already reached the economic corridor stage from the transport corridor. TRACECA project and the Pan-European Corridor can be given as examples of economic corridors. Table 2 summarizes the characteristics of the development and stages of the international corridors. 


\section{Table: 2 \\ The development stages of International Corridors}

\begin{tabular}{|c|c|c|}
\hline Stage & Corridor & Definition \\
\hline 1. Stage & Transport corridor & Physical connection to one region with one form of transportation \\
\hline 2. Stage & Multi-mode transport corridor & $\begin{array}{l}\text { Physical connection to one region with different forms of } \\
\text { transportation or integration of transportation forms }\end{array}$ \\
\hline 3. Stage & Logistics corridor & $\begin{array}{l}\text { Inter-regional physical connection allowing all kinds of } \\
\text { transportation forms besides presenting all logistics services such as } \\
\text { storage, handling and customs clearance }\end{array}$ \\
\hline 4. Stage & Economic corridor & $\begin{array}{l}\text { The corridors that are attractive for investments and economic } \\
\text { activities in the developing regions, in which utilization of all kinds } \\
\text { of transport forms and existence of all kinds of logistics facilities } \\
\text { are prerequisite. }\end{array}$ \\
\hline
\end{tabular}

\subsection{Effects of the Transport Corridors on Regional Development}

Transportation activities has given direction to trade since the Middle Ages. Trade has always gained improvement along the routes where transportation activities take place. Especially, the "Silk Road" known during the Middle Ages and modernized today, has had a great impact on the development of trade. Silk Road has emerged as a route connecting two great civilizations of China and The Roman Empire and wide geographic area along both sides of this road, between these two empires, exchange of goods and idea has been carried out (Tozar et all, 2011: 3). In areas along the route, many caravanserais and inns have been built, trade has created positive economic and social impacts on these areas.

After the $15^{\text {th }}$ century The Silk Road has begun to lose its importance along with the geographical discoveries. However, trade has continued to be performed through the new routes. There are numerous trade routes allowing trade of goods and passenger mobility, known as "transport corridors", and these create economic effects over the areas where they exist.

Today, the international transport corridors located in the continents of Asia and Europe which are stated as economic, can be analyzed in three categories:

i European Transport Corridors: Pan-European Transport Networks, (TransEuropean Transport NetworkTEN-T, Trans-European North-South Motorway Network-TEM, The Trans-European Rail Network-TER),

ii Asian Transport Corridors: Asian Highway Network, Trans-Asian Railway Network-TR, 
iii Eurasian Transport Corridors: Euro-Caucasus-Asia Transport Corridor (TRACECA).

Since the transport corridors has great importance especially in increasing the trade between the countries and cities on and around the corridor accelerates the regional development and regional integration. The larger the area of the transport corridor becomes, the area it affects gets larger as well.

The impact of transport corridors on regional development arises primarily from the effects that result in the goods market and labor market. The effectiveness of transport corridor is to enable realization all logistics processes such as transportation, customs clearance, storage, handling along the supply chain faster and less costly by saving time.

Decrease in the transport activities has two important effects. Firstly, it becomes easier to access to the production areas where cost is low. And secondly, the manufactured goods can be transported easily to the desired country markets. This situation, shows its effect primarily in the goods markets. Decrease in the transportation costs bring along focusing on production and achieving the scale economies. Since the transportation costs have a significant share in the cost of goods which are subject to international trade, the decrease in transportation costs provides the companies with the power to compete (ISEDAK, 2011: 3-5). On the other hand, the decrease in transportation costs has significant impact on effectiveness and the size of labor markets. People can expand the fields where they are looking for jobs, more people are in trial of searching for jobs. While this situation affects the production costs per unit by way decreasing the wages it increases employment (Pike et al., 2011: 438-443).

These effects experienced in the product markets and labor markets in the areas where transport corridors exist, result in both the companies to expand their current activities and in increase new company establishments as well. Thus, with the increase in employment and production capacity the trade increases, increasing trade turns the region to be attractive for the foreign capital and at same time because these activities will trigger the tourism activities, regional development will be realized (Irish Spatial Strategy, 2005: 13-25). Figure 2 shows the impact of transport activities on the regional development.

\section{TRACECA and Regional Development}

TRACECA which is called as the historical Silk Road is a multi-mode transportation corridor project developed by the European Union in order to integrate the continents of Europe and Asia by connecting them to each other via Black sea and Caucasus. The corridors within the scope of the current project has been serving road, sea and rail transport and additionally combined transport (Tozar et all., 2011: 5). 
Fig. 2

\section{Transport Activities and Regional Development}

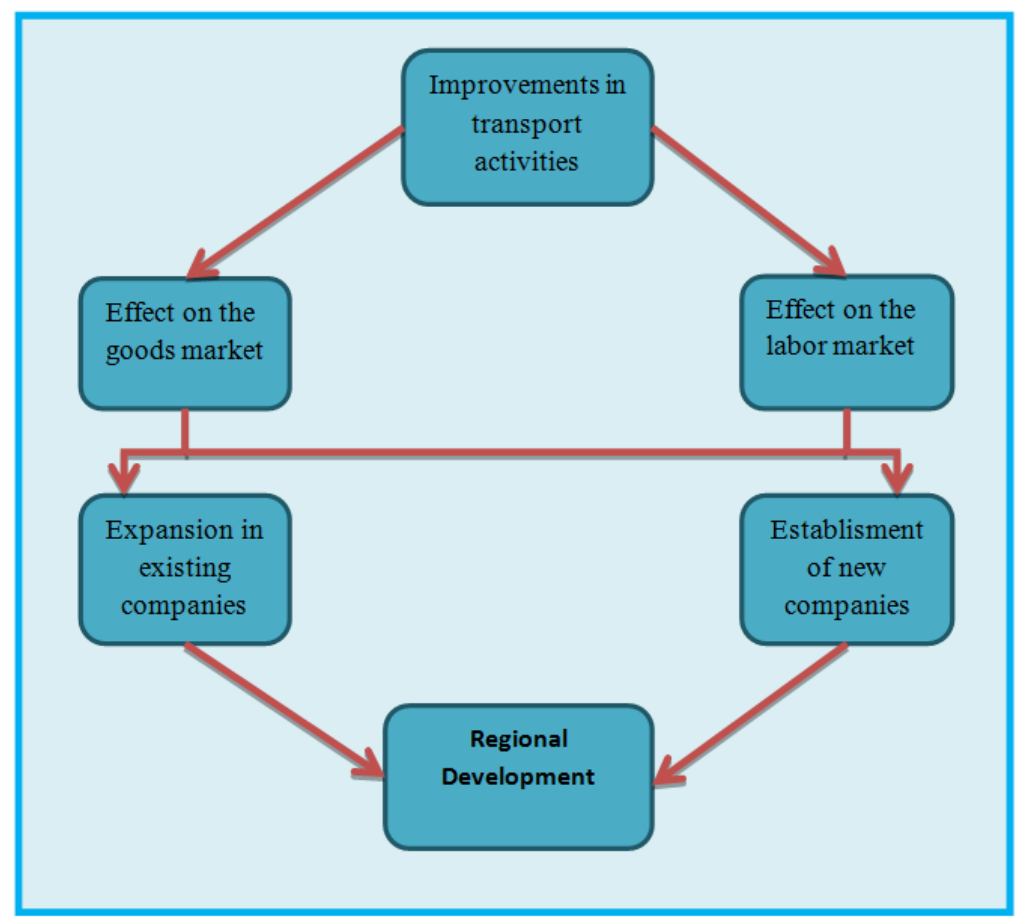

Source: Irish Spatial Strategy, 2005:15.

The TRACECA project primarily aims to harmonize the customs and foreign trade regulations among the member countries, to accelerate the trade and the goods movement and to ensure the integration of the developing countries which are rich of underground resources with the developed country markets, by the of developing the transportation infrastructure of the member countries, enabling them to access to the European and global markets, strengthening their freedom and economic levels, establishing the connection of the TRACECA corridors and the Trans-European Network (TEN), supporting the regional cooperation, with project increasing the interest of the international finance institutions for the member countries have been determined as priority targets (Erdal, 2005: 112-113).

With the TRACECA project, sea, road and rail routes have been focused. As seen in the Map 1, as the sea route the ports on the Black sea and the Caspian Sea have been 
specified. And road and rail routes have been determined in a way that will provide transportation to other countries starting from Ukraine via Turkey. In fact, TRACECA can be specified as the East-West corridor aimed to connect the Central Asian Republics to Europe via the Caucasus by the European Union and covering all transportation systems mainly the railway.

\section{Map 1 \\ TRACECA Corridor}

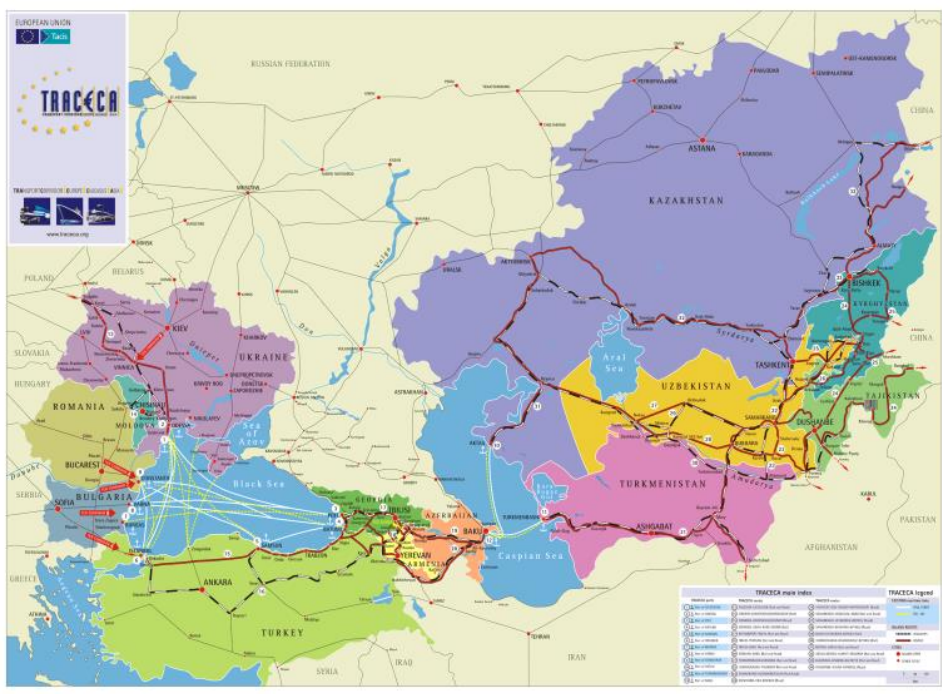

Source: TRACECA Turkish National Secretariat, <http://www.traceca.org.tr>.

TRACECA has a special importance because of being the only project related with Eurasian region transport corridor that receives major financial and technical support from international organizations. Having strategic importance due to providing alternative transport line to Europe, the TRACECA aims to make the historical Silk Road become an important trade route again by reestablishing the trade links between the Middle Asian and Far Eastern countries (Tutar et all., 2009: 2).

The "Basic Multilateral Agreement (MLA)" has an important role in the implementation of the TRACECA. MLA is an agreement signed by the Heads of States and Governments of a total of 12 countries on September8, 1998 for the development of EuropeCaucasus-Asia Transport Corridor. Countries included in the agreement are Turkey, Azerbaijan, Bulgaria, Georgia, Kazakhstan, Kyrgyzstan, Moldova, Romania, Turkey, 
Ukraine, Tajikistan and Armenia; there are 14 countries in the TRACECA with the subsequent approval of Iran and Turkmenistan's application.

\section{Chart 1 \\ Export in the TRACECA Countries (\$)}

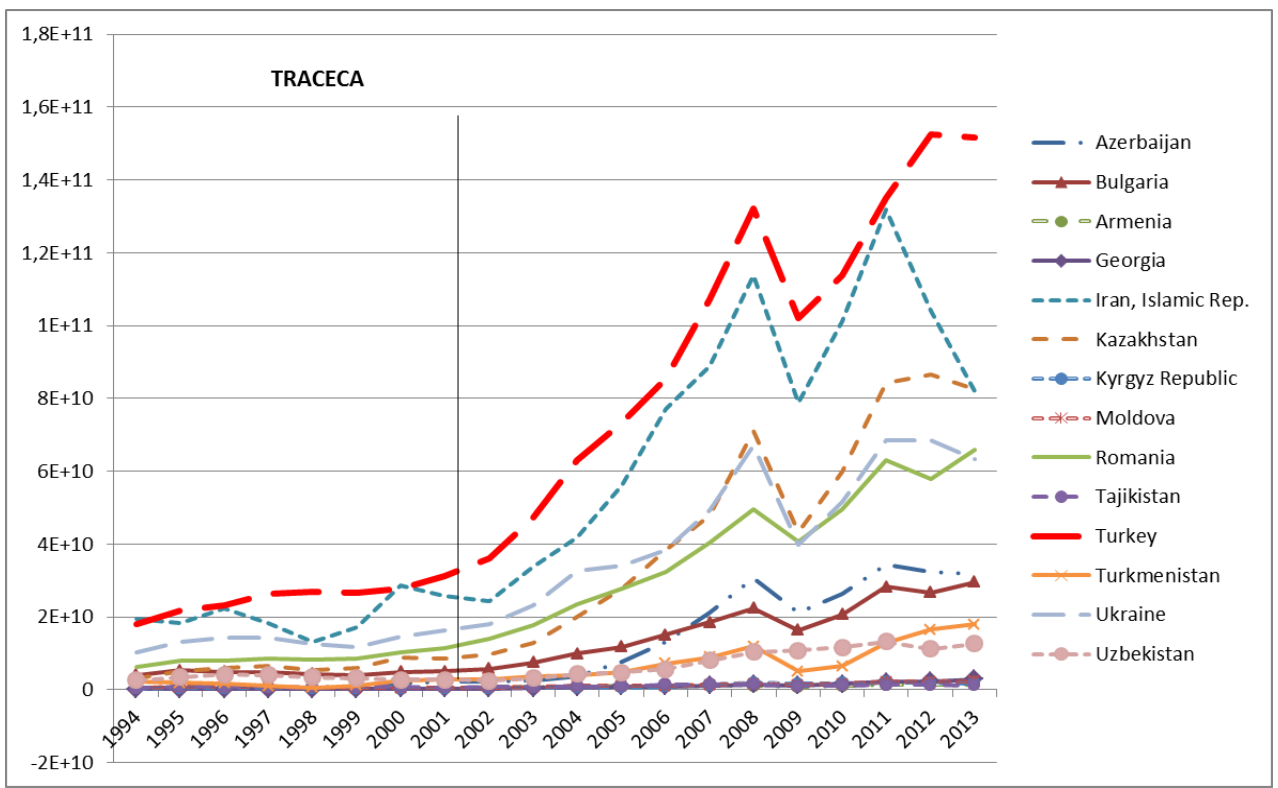

Source: World Bank Data, 2015

Within the scope of MLA, the main objectives of the TRACECA can be specified as ensuring the development of economic relations, trade and transportation links in Europe, The Black Sea, The Caucasus, the Caspian and Asian regions, the promotion of international transport of goods and passengers, to guarantee traffic safety, security of the goods and environmental protection, equal competition between different modes of transportation (Tozar et all, 2011: 6-8).

TRACECA transport corridor has been making significant contributions to the economic development in the member countries and in the "Eurasia" where these countries are located. The most important one of these effects is at the dimension of international trade. With the TRACECA, fast and cheap transportation operations developed in the member countries has led to increase their trading volumes. When looked at the export figures of the countries involved in the TRACECA, as seen in Chart 1, the rising trend in the export figures after 1998 which is the year that the project started, (excluding the breakpoint period 
occurred in 2008 due to the global crises) is noteworthy. Among the TRACECA countries, Turkey is the country where the highest export growth has been realized. The strategic importance that Turkey has, has increased further with the TRACECA.

The reason of the increasing trend in exports of the member countries is not only the TRACECA. The trade agreements between countries, being included in the international integration, government policies for export are also among the reasons of increase in export. However, as the effectiveness of the export activities increase and the cost decreases export increases. Therefore, member countries give strategic importance to the multi-mode TRACECA corridor as an additional link in opening to European markets and in terms of adapting to global trade. Besides, the TRACECA program has been keeping the transit fees at competitive level. Thus, a close collaboration has been created between the governments and the transport sector and procedures concerning border crossing has been facilitated. The increase in the freight transportation due to the TRACECA Corridor being the shortest, the fastest, and the cheapest land connection in east-west direction increases the interest of the logistics companies in this route (OKA, 2010: 6). TRACECA Corridor has significant importance particularly for the Central Asian countries that have no connection to the sea in terms of developing their trade and transport networks (DOĞAKA, 2014: 9).

As a tool of development and international integration the TRACECA has been more powerful since the day it was established. The three main reasons for this situation can be specified as follows:

i The European countries, in order to increase trade between regions, are interested in a living link with the TRACECA member countries.

ii Many TRACECA countries (such as Kazakhstan, Kyrgyzstan, Azerbaijan, Tajikistan) are surrounded by land have been able to enter the world market by taking advantage of the TRACECA region and waters by the help of agreements based on facilitating trade and transport and common policies.

Iii In the TRACECA region common policies have been implemented in transport sector, and security-building measures have been taken (Tutar et all., 2009: 14).

With acceleration of infrastructure works within the scope of TRACECA project, decrease in the average duration of export realization is also observed in most of the member countries. For example, while the average export realization period was 20 days in Turkey in the year of 2005, in the current situation it has decreased to 13 days. Georgia has been the most striking country in the change of the average export realization period. The period being 54 days in 2005 has dropped down to 9 days. Georgia has a strategic geopolitical position and, by focusing particularly on the East-West corridor which is politically more stable, is developing herself as an international transit corridor. Transport policy of the 
Georgian government is being shaped in the framework of improving the sustainable development conditions in the transport sector, integrating with the international transport system, and ensuring the safe transport of the passengers and goods. This situation is reflected to export in which transportation is the most important issue.

Romania which is another country attracting attention, is one of the most important intersections in Europe's foreign trade. Improvement of the transportation infrastructure with institutional strengthening, investments and rehabilitation policy have been included in the scope of the government strategy. National infrastructure is being developed in accordance with European Union standards. Romania, in the period 20002005 , especially in the areas of roads, has made progress in harmonization of privatization and legislation in the transport sector, has started works for increasing their efficiency by realizing the reorganization of the institutions which are responsible for transport on river, lake and sea. One of the results on which these works became effective is that the average export realization period has dropped down to 13 days from 28 days (PABSEC, 2005: 2122). Chart 2 shows the average duration of the export realization in the TRACECA countries.

\section{Chart 2}

\section{The Average Duration of the Export Realization in the TRACECA Countries}

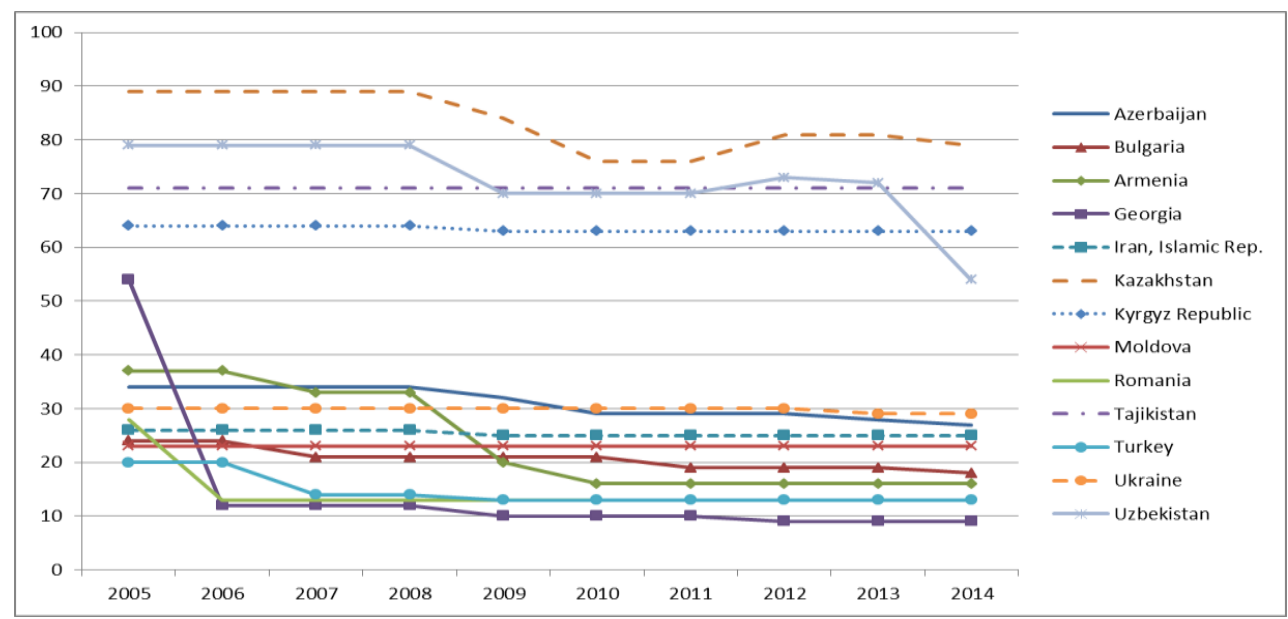

Source: World Bank Data, 2015.

Transportation corridors are also effective on logistics performance of countries and regions. "LPI (Logistics Performance Index)" which has been carried out by the World Bank since 2007 and in which the transportation infrastructure, transportation costs, effectiveness of the border customs operations, logistics competence, monitoring the process 
and realization periods are being analyzed according to the countries can be evaluated as reflection of the results of the policy implemented towards improving the transportation corridors. The LPI results of the 14 countries included in the TRACECA are shown on Table 3.

Table: 3

LPI (Logistics Performance Index) in TRACECA Countries: Overall (1=low to 5=high)

\begin{tabular}{|l|c|c|c|c|}
\hline & $\mathbf{2 0 1 4}$ & $\mathbf{2 0 1 2}$ & $\mathbf{2 0 1 0}$ & $\mathbf{2 0 0 7}$ \\
\hline Turkey & 3,50 & 3,51 & 3,22 & 3,15 \\
\hline Romania & 3,26 & 3 & 2,84 & 2,91 \\
\hline Bulgaria & 3,16 & 3,21 & 2,83 & 2,87 \\
\hline Ukraine & 2,98 & 2,85 & 2,57 & 2,55 \\
\hline Kazakhstan & 2,70 & 2,69 & 2,83 & 2,12 \\
\hline Armenia & 2,67 & 2,56 & 2,52 & 2,14 \\
\hline Moldova & 2,65 & 2,33 & 2,57 & 2,31 \\
\hline Tajikistan & 2,53 & 2,28 & 2,35 & 1,93 \\
\hline Georgia & 2,51 & 2,77 & 2,61 &.. \\
\hline Azerbaijan & 2,45 & 2,48 & 2,64 & 2,29 \\
\hline Uzbekistan & 2,39 & 2,46 & 2,79 & 2,16 \\
\hline Turkmenistan & 2,30 &.. & 2,49 &.. \\
\hline Kyrgyz Republic & 2,21 & 2,35 & 2,62 & 2,35 \\
\hline Iran, Islamic Rep. &.. & 2,49 & 2,57 & 2,51 \\
\hline
\end{tabular}

Source: World Bank Data, 2014.

TRACECA has also been positively affecting the countries' social and cultural relations, it has also been effective in the increase of the tourism revenues as much as in the increase of the international trade. Tourism is a displacement activity in which transportation routes and vehicles are used. Tourism activities that started depending on the transport systems also stimulates the transport. However inadequacy of the existing routes despite the tourism potential of the countries, lack of providing high quality and reliable transport services, negative practices at the borders and high transportation costs have been creating a hindrance for the development of tourism (Doğaner, 1998: 1).

Within the TRACECA, overcoming those problems and revealing the tourism potentials of the member countries is aimed. In this respect, with the decrease in the transportation costs and reduction in the duration of transportation, the number of commercial and touristic purposed trips have been increasing every other day, due to the high cost of transportation previously less preferred long-distance touristic centers have been attracting more tourists. The transportation infrastructure becoming suitable for all types of transport has been the most important reason of the decline in transport costs. Improving the quality and infrastructure of transport and reduction in the overall costs have positively affected the international passenger transport and thus the tourism activities (Oval1, 2008: 
167). This situation leads to increase of tourism revenues Chart 3 shows the trend in tourism revenues between the years 1998 - 2011 in the TRACECA countries. Turkey is in the position of the country among the TRACECA countries that has the most tourism revenues and has the highest growth rate of tourism revenues.

\section{Chart 3}

\section{Tourism Revenues in the TRACECA Countries (International Tourism, Receipts)}

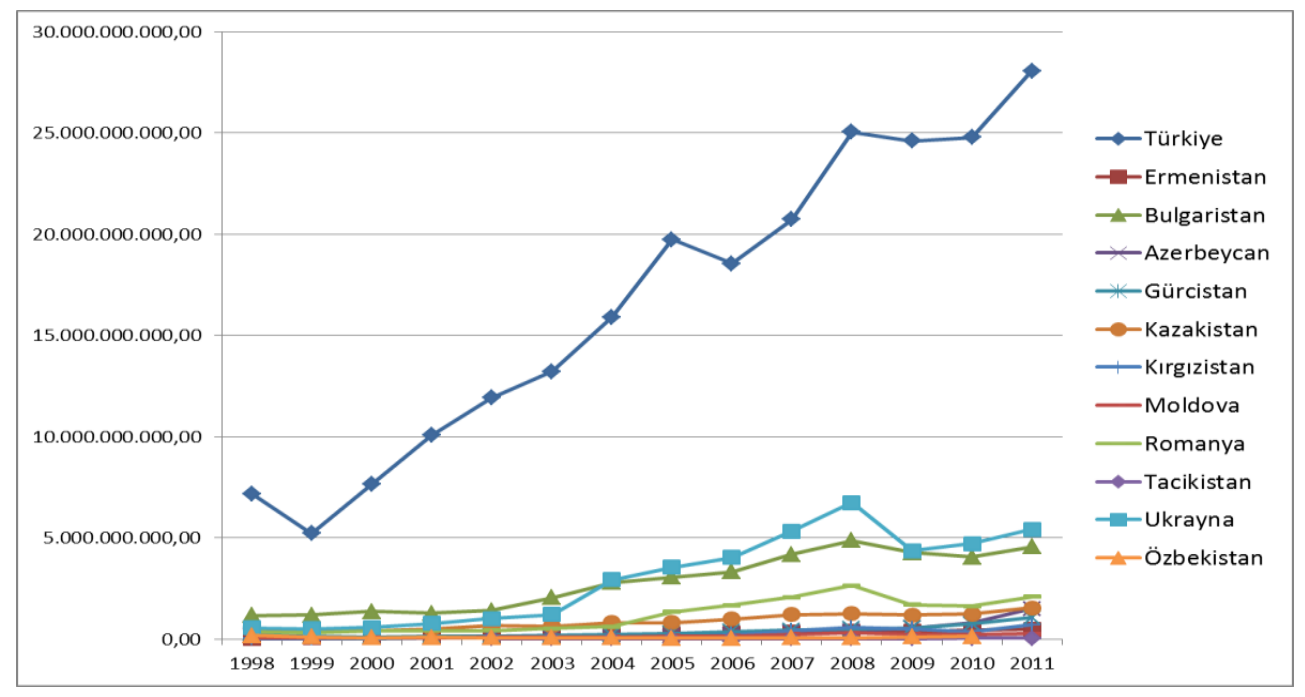

Source: World Bank Data, 2015.

When the TRACECA Countries are evaluated with general economic data, the superiority that Turkey has compared to other countries is obviously seen. One of the most basic reasons of this is that, as seen on Map 2, with the advantage of its geographical location Turkey has an important transportation network potential for the use of all types of transport. With its $8333 \mathrm{~km}$ coastline and the ports it has, it is an important transit country for maritime transport which is the most cost-effective mode of transport with overseas countries. Besides, with its strong transport infrastructure, it is located on the intersection of the TRACECA and Pan-European transport networks. With regard to railroad transport, infrastructure investments has increased in the recent years, high-speed train projects have been implemented in many regions. In addition to this, the number of active airports in relation to air transport has been increased, significant increases have been observed in the number of passengers carried by airline. An important part of these developments, in the scope of TRACECA have been serving to the purpose of establishing a transport network integrated with the other member countries. Developments in transportation activities, 
besides increasing the overall exports figures of Turkey, also have caused the developing regions to participate in the foreign trade, and have had a positive impact on employment in these regions. Especially the TRACECA network passing through the eastern provinces has a significant impact on the development of these regions.

\section{Map 2}

\section{TRACECA Network Located on Turkey}

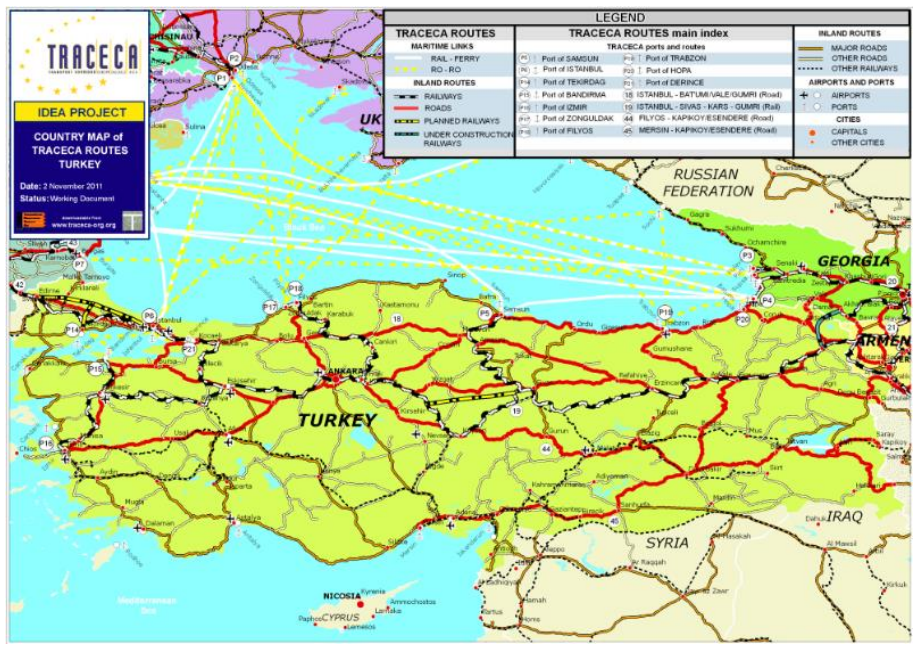

Source: TRACECA Turkish National Secreteriat, <http://www.traceca.org.tr>.

Countries such as Uzbekistan, Kyrgyzstan, Moldova, Tajikistan included in the TRACECA countries are the countries that are surrounded by land. Therefore, it is expected that TRACECA transport corridor, will have a great impact on enabling the maritime connection of these countries and thus on the increase in the trade to be made with overseas countries, and on the reduction of transport costs. In the countries mentioned, establishment of a transport infrastructure system integrated with the neighboring countries is aimed in order to realize the expected benefits related with the TRACECA corridor. When the projects planned in this context, it is expected that development process in the Caucasus region will be accelerated (East Invest, 2013).

\section{Conclusion}

The transport corridors defined as a whole of one or more routes connecting the centers in different countries where economic activities are carried out have a significant 
impact on realization of the regional economic development. International transport corridors, ensures the increase of the trade activities by creating transport infrastructure that allows the use of different modes of transport between the countries on the routes.

TRACECA which is called as the modern Silk Road is a project towards realizing the transport activities in the Eurasia region with more reasonable costs, and without interruptions. Transportation has a great importance in realizing the economic activities which are the key to development. Tourism and foreign trade comes at the top of these economic activities. The effectiveness and the efficiency of transportation is primarily reflected in the foreign trade, export and import is realized in shorter time and at lower cost. Rise in the import and export causes the companies to produce more and an increase in the employment. This situation enables the countries take faster pace in the path of development.

On the other hand, transportation has been effective on the international tourism activities. The decline in the transport costs leads people to change more places for tourism and trade purposes. This case causes the tourism centers to improve and accelerates the regional development. At this point, it is aimed that the TRACECA project, making the transportation effective in the member countries, contribute to the economic development in every aspect.

Turkey among the TRACECA member countries, has been offering significant opportunities in terms of multi-modal transport with its geographical location in the region and therefore has an important place within the scope of TRACECA corridor. When observed its economic indications after the year of 1998 when Turkey participated in the TRACECA corridor, with completion of the planned infrastructure projects important developments stand out. Increase in exports, becoming an attractive region for the foreign capital, increased demand in the manufacturing industry can be given as examples of these. In addition, significant increases have occurred in passenger transport and in tourism activities, the share of tourism income in the national income has also increased.

One of the countries among the eastern European TRACECA member countries that attracts the most attention with developments in terms of export has been Romania. In Romania which is situated as location on the crossroads of Europe's foreign trade, the realization period of export has dropped down to 13 days from 28 days during the past 10 years. And the export has increased from 8,3 billion $\$$ to 65,8 billion $\$$. Romania holds the second position among the TRACECA countries in the LPI rankings.

In Georgia, another TRACECA country having strategic position especially the decrease in the realization period of export is noteworthy. The period that was 54 days in the year of 2005, has dropped down to 9 days in 2014. One the most important reasons for this 
is that Georgia being especially a transit country on the oil pipeline has had more role after TRACECA.

When the Caucasus countries included in the TRACECA are compared with other countries, they take place in the bottom rows in terms of export figures and logistics performance. However, with the completion of the planned infrastructure projects, it is expected that these countries become an important transit region on the Europe-Asia connection and gain increase in the international trade and tourism revenues. Consequently, by the way of increased employment with the inflow of foreign capital, it is estimated that regional development will be realized in these countries in the oncoming years.

\section{References}

Arnold, J. (2006), Best Practices in Corridor Management, The World Bank Publications, Washington, 2006, <http://siteresources.worldbank.org /INTTRANSPORT/Resources/ 336291-1227561426235/5611053-1229359963828/itc-1-11-07.pdf>, 14.09.2013.

Arslan, K. (2005), "Bölgesel Kalkınma Farklılıklarının Giderilmesinde Etkin Bir Araç: Bölgesel Planlama ve Bölgesel Kalkınma Ajansları", İstanbul Ticaret Üniversitesi Sosyal Bilimler Dergisi, 4(7), 275-294.

Banomyong, R. (2008), "Logistics Development Study of The Indonesia-Malaysia-Thailand Growth Triangle (IMT-GT)", The 2nd Working Group Meeting on Infrastructure and Transportation, Langkawi, Malaysia, 26-27 June 2008, <http://www.imtgt.org/Documents/Studies/Logistics-Development-Study.pdf>, 03.06.2010.

Beceren, E. (2004), “Bölgesel Rekabet Gücü”, Süleyman Demirel Üniversitesi İIBF Dergisi, 9(2), 279-302.

DOĞAKA - Doğu Akdeniz Kalkınma Ajansı (2014), Lojistik Sektör Raporu 2014, Doğu Akdeniz Kalkınma Ajansı Yayını, Hatay. <http://www.dogaka.gov.tr/Icerik/Dosya/ www.dogaka.gov.tr_444_ZU5L89VC_Lojistik-Sektor-Raporu-2014.pdf>, 28.11.2014.

Doğaner, S. (1998), “Türkiye Ulaşım Sistemleri Turizm ve Çevre İlişkileri”, İstanbul Üniversitesi Edebiyat Fakültesi Coğrafya Bölümü Coğrafya Dergisi, S. 6, İstanbul.

Durgun, A. (2011), "Bölgesel Kalkınmada Turizmin Rolü: Isparta Örneği”, Süleyman Demirel Üniversitesi, SBE, Yayınlanmamış Yüksek Lisans Tezi, Isparta.

East Invest, <http://www.east-invest.eu/en/Investment-Promotion/ukraine-2/ukraine-transport-andlogistics>, 02.09.2013.

Erdal, M. (2005), Küresel Lojistik, UTIKKAD (Uluslararası Taşımacılık ve Lojistik Hizmet Üretenler Derneği) Yayınları, İstanbul.

Florkowski, S. \& E.N. Jan (2007), Regional Dynamics in the East-West Transnational Transport Corridor, Blekinge Institute of Technology, Karlskrona, Sweden, <http://www.bth.se/tks/ctup.nsf/bilagor/EastWestFinalReport_pdf/\$file/EastWestFinal Report.pdf>, 05.09.2013.

Ildırar, M. (2004), Bölgesel Kalkınma ve Gelişme Stratejileri, 1.b., Nobel Yayınları, Ankara. 
Irish Spatial Strategy, <http://www.irishspatialstrategy.ie/docs/pdf/Transport\% 20and\%20Regional\%20Development.pdf $>$, 05.09.2013.

İSEDAK (2011), A Study of International Transport Corridors in OIC Member Countries, <http://www.comcec.org/UserFiles/File/ulastirma/IDB-TransportCorridors-Study.pdf>, 12.08.2013.

Kebapçı, H. (2011), "Bölgesel Kalkınmada Dış Ticaretin Rolü: Burdur-Isparta-Antalya İllerinin Karşılaştırması", Süleyman Demirel Üniversitesi, SBE, Yayınlanmamış Yüksek Lisans Tezi, Isparta.

Litman, T. (2010), Evaluating Transportation Economic Development Impacts, Victoria Transport Policy Institute, Canada. <http://www.vtpi.org/econ_dev.pdf>, 10.09.2012.

Mulenga, G. (2013), "Developing Economic Corridors in Africa”, AFDB (African Development Bank Group) Regional Integration Brief, Regional Integration and Trade Department, No.1, <http://www.afdb.org/fileadmin/uploads/afdb/Documents/ Publications/Economic\%20Brief\%20\%20Developing\%20Economic\%20Corridors\%20in $\% 20$ Africa $\% 20 \% 20$ Rationale $\% 20$ for $\% 20$ the $\% 20$ Participation $\% 20$ of $\%$ 20the\%20AfDB.pdf>, 09.09.2013.

OKA - Orta Karadeniz Kalkınma Ajansı (2010), “Ukrayna Ülke Raporu”, Orta Karadeniz Kalkınma Ajansı Dokümanı, <http://www.oka.org.tr/Documents/Ukrayna_Ulke_Raporu.pdf>, 01.08.2013.

Ovalı, S. (2008), “TRACECA Projesi ve Türkiye”, International Journal of Economic and Administrative Studies, 1(1), 151-170.

Özgür, E.M. (2010), "Bölgesel Kalkınma”, Ankara Üniversitesi Dil Ve Tarih-Coğrafya Fakültesi Coğrafya Bölümü Ders Notları, <http://www.geography.humanity.ankara. edu.tr/ders_notu/COG323.pdf>, 11.09.2013.

Öztürk, N. \& U. Meral (2010), "Bölgesel Kalkınma Dinamikleri: Bölgesel Dengesizliklerin Ortaya Çıkmasında Rol Oynayan İktisadi Etmenler”, Cumhuriyet Üniversitesi İktisadi ve İdari Bilimler Dergisi, 11(2), 91-110.

PABSEC - Parliamentary Assembly of the Black Sea Economic Cooperation (2005), "Karadeniz Bölgesi'nde Ulaşım Altyapısının Geliştirilmesi”, Ekonomi, Ticaret, Teknoloji ve Çevre İsleri Komisyonu Raporu, (Raportör: Sn. David Saganelidze), Tirana, <http://www.pabsec.org/pabsec/aksisnet/file/13-GA26-EC25-REP-05-tr.doc\& $\mathrm{sa}=\mathrm{U} \& \mathrm{ei}=\mathrm{tWTBVMPRDIKGzAPvhYCIBw \& ved=0CAYQFjAB \& client=internal-ds-}$ cse\&usg=AFQjCNEy01_OID4IIPKnzoN36amu_w5pqw>, 18.10.2014.

Pike, A. \& R.P. Andres \& T. John (2011), Handbook of Local and Regional Development, Routledge.

Rodrigue J.P. (2013), The Geography of Transport Systems, New York: Routledge.

Saatçioğlu, C. \& O. Karaca (2013), "Ulaştırma Altyapısı ve Bölgesel Gelir Farklılıkları: Türkiye İçin Ampirik Bir Analiz", İşletme ve İktisat Çalışmaları Dergisi, 1(1), 1-11.

Tozar, B. \& I. İzzet \& Ö. Seçil (2011), Yine Yeni Yeniden Ípekyolu, Ulaştırma Bakanlığı TRACECA Türkiye Ulusal Sekreterliği Yayını, Ankara.

Tutar, E. \& F. Tutar \& M.V. Eren (2009), "Uluslararası Ulaşım Koridorunda Yeni Bir Açılım: Traceca Projesi ve Türkiye”, Mevzuat Dergisi, 12(139), ISSN 1306-0767.

Zeybek, H. (2007), "Ulaşım Sektöründe İntermodalite ve Lojistik Alanındaki Gelişmeler ve Türkiye'ye Yansımaları”, Gazi Üniversitesi SBE, Yayınlanmamış Doktora Tezi, Ankara. 